\title{
The Demand-Control Model at Work and Satisfaction with the Couple Relationship
}

\author{
MARINA ORTIZ-LÓPEZ \\ Department of Social Psychology. University of Granada, Spain. \\ Email: marinaortiz@ugr.es \\ Tel: +34685208633 \\ ANTONIA CALVO-SALGUERO \\ Department of Social Psychology. University of Granada, Spain. \\ Email: acalvo@ugr.es \\ Tel: +34958246295
}

\begin{abstract}
The overall aim of this study was to analyze if the characteristics of the job emerged as direct predictors of the satisfaction with the couple relationship and, if applicable, identify those characteristics predicting low satisfaction, with a view to contribute to the prevention of psychosocial risks that affect social health in organizations. For the achievement of this aim, Karasek's (1979) two-dimensional model was taken as a theoretical frame of reference. It focuses on job demands and the control that organizations offer their employees in order to address these demands. The sample of participants was formed by 124 employees. The results showed that the quadruple typology proposed by the two-dimensional model, as well as control had significant effects on satisfaction. Participants with low control presented lower levels of satisfaction than participants with high control. The results concluded that the characteristics of the job, as well the autonomy, the possibility of developing abilities and creativity, influence satisfaction with the couple relationship.
\end{abstract}

Keywords: Job-Demands, Job-Control, Satisfaction with the Couple Relationship, Prevention of Psychosocial Risks at Work, Occupational Health.

\section{Introduction}

Family affective relationships are essential for people's development and well-being at physical and psychological levels and a decisive element in the socialization of future generations (Mora, Gómez, \& Rivera, 2013). Many studies have revealed that separation or divorce jeopardize these relationships, resulting in harmful consequences at social, educational, occupational, personal and clinical levels, not only in couple relationships, but also in children (Cáceres, 2012; Mora, Gómez, \& Rivera, 2013; Moral, 2008; Zicavo, 2008). Data from diverse surveys reveal that in the last 10 years, in many developed countries' current society, the divorce rate has doubled (Eurostat, 2011). In Spain, according to the last data of the Spanish National Institute of Statistics (INE, 2012), the number of divorces increased by $0.3 \%$ in 2016 and, according to the "Business Insider" site, Spain was ranked fifth globally in 2014 with $61 \%$ of breakups. Therefore, the analysis of the factors that influence the stability and quality of couple relationships is of relevance, since they have significant implications for each family member's personal life. 
The present study focuses on the analysis of people's degree of satisfaction with their couple relationships. Given that there are numerous definitions, in this study it will be understood as each couple's subjective evaluation or global assessment of their couple or spouse, and their relationship (Graham, Diebels, \& Barnow, 2011). The method chosen for the implementation is Booth and Edwards (1983) Marital Satisfaction Index. This instrument was developed to assess family breakdown situations or instability in couple relationships and it has proved to be effective in predicting divorce or separation.

There is a wide range of factors that predicts satisfaction with couple relationships including sociodemographic, dispositional, health and well-being, physical and psychological aggression variables (Day, 2009; Faulkner, Davey, \& Davey, 2005; Kim, Capaldi, \& Crosby, 2007; Vera-Herrero, 2011; Villamizar-Carrillo, 2009; Weinstein, Powers, \& Lavarghetta, 2010).However, few studies have analyzed variables related to work.

In the last past decades there have been important changes in the nature of work, such as the great amount of time that work requires, job's greater complexity due to new technologies, bigger psychological requests and demands to increase productivity in less time, greater uncertainty and demands of adaptation, inter alia (Gil-Monte, 2012). They turn the job role into a potential source of occupational and psychosocial risk that can affect not only employees' physical and mental health, but also their social health, and, therefore, their couple relationships.

Investigations that analyze the relationship between work and family assumed that the experiences at work are not independent from employees' personal and family life. Thus, attitudes, emotions, stress and behaviors at work can be transferred to family domain (spillover) and vice versa Bakker \& Demerouti, 2012; Demerouti, Bakker, \& Schaufeli, 2005). From this perspective, some studies have found that the characteristics of the job create a family-work conflict in employees, which puts stress on them. They have also discovered how it, in turn, affects satisfaction with family, couple relationship and even life satisfaction negatively (Allen, Herst, Bruck, \& Sutton, 2000; Carlson, Kacmar, \& Williams, 2000). Other studies have shown that overload and role conflict at work are associated with negative stressful emotional states and that they are, in turn, related to annoyance and turning away during marital interactions (MacEwen \& Barling, 1994). Other studies have equally shown that high levels of work-related stress predict an increase of turning away from dyadic interactions (Schultz, Cowan, Pape-Cowan, \& Brennan, 2004) or a decrease of marital adjustment (Perry-Jenkins, Repetti, \& Crouter, 2000).

A common point in most of these investigations is that the direct predictor of the results in the field of couple relationships, such as marital satisfaction, is a negative stressful internal state in response to experiences in work roles (experience of work-related stress) (Perry-Jenkins, Repetti, \& Crouter, 2000). Nevertheless, there is no study that has analyzed the characteristics or traits of the job as direct predictors of the satisfaction with the couple relationship. This analysis is needed so that organizations can comply with the legal regulations in matters of prevention of occupational risks. In Spain, Act 31/1995 of $8^{\text {th }}$ November 1995 on the Prevention of Occupational Risks, according to Article 14, establishes that organizations are obliged to prevent the potential occupational risks derived from work or the organization and to guarantee employees' health and well-being. According to the WHO (2006), guaranteeing employees' health implies guaranteeing their full physical, mental and also social well-being. Social health is mainly reflected in people's full involvement in their social life, that is, in their decisions, behaviors, emotions, attitudes, interactions with their social and family environment and, therefore, in their couple relationships (MartínSanz, 2009).

Thus, from this perspective, the compliance of this regulations requires organizations' concern for their employees' full well-being. Likewise, Article 15 on Principles of Preventive Action involves, inter alia, avoiding risks and adapting the work to the employees, especially concerning the conception of the job. Therefore, it is necessary to know the factors of the job and/or organization that imply risks for employees' full and healthy participation in their social and family life, as well as in their couple relationships. 
That is why the main aim of this study is to analyze the potential relationship between the characteristics of the job as direct predictor of satisfaction with couple relationships. To achieve this, the Demand-Control Model (Karasek, 1979; Karasek \& Theorell, 1990) is taken as a theoretical frame of reference. This model is one of the most used in the analysis of psychosocial risks at work and has obtained empirical evidence in predicting negative effects, such as higher risk of coronary disease, psychosocial and musculoskeletal disorders, exhaustion, stress, depression, mental and cardiovascular health (Collins, Karasek, \& Costas, 2005; Karasek, 1979; Karasek \& Theorell, 1990; Linzer et al., 2002; Pelfrene et al., 2002), among many others. However, if we attend to the theoretical premises of the investigations carried out regarding the relationship family-work, this model could also be applied to the analysis of social health or well-being.

The model is based on two dimensions: work's psychological demands and the quantity or level of control that the employees have on these demands. Psychological demands refer to the quantitative level of work that the employees are required to do, such as workload, the time available to do it, the attention required or the interruptions (Karasek, 1979; Karasek, Baker, Marxer, Ahlbom, \& Theorell, 1981).

Employees' control depends on the resources provided by the organization and, in this sense, two types of resources stand out: the chances to develop one's abilities and autonomy to make decisions at work. This control is the essential dimension of the model and it has been proved to be the most important in relation to health. The level of these resources moderates the relationship between the quantity of demands and employees' psychological and behavioral experience.

If control is present in an adequate quantity to allow the employees to deal with high demands, it emerges as a positive, protective or health promoter factor, since it leads them to be motivated to learn and develop new behavior patterns. On the contrary, if it is missing or it is insufficient to address high demands, it emerges as a negative factor, presenting risks for health, which can create psychological stress and reduce well-being.

This model includes the combination of the two dimensions, depending on them being high or low, which result in 4 situations: a) High-strain situation (high demands and low control); b) Active situation (high demands and high control); c) Low-strain situation (low demands and high control); d) Passive situation (low demands and low control). See Figure 1.

The model predicts that high-strain and passive situations must be addressed from the perspective of preventing occupational risks, since they can have negative effects on health and cause learning other harmful behaviors for employees and organizations.

According to the model, negative consequences on health do not depend so much on the quantity of demands, but on not having chances to control and solve them.

Taking this model as a theoretical frame of reference, the main objective of the present study was to test if the job characteristics proposed by this model predict satisfaction with couple relationships. Given that the model includes two approaches of analysis (Karasek, 1989), namely, additive approach or combination of the dimensions according to them being high or low, and interactive approach or approach of multiplicative effects of the dimensions, two hypotheses were established. From the additive approach, we established:

Hypothesis 1.

The quadruple typology of situations that postulates the model has a significant effect on the satisfaction with couple relationships, such that participants in high-strain situation (high demands and low control) will obtain the lowest levels of satisfaction. 


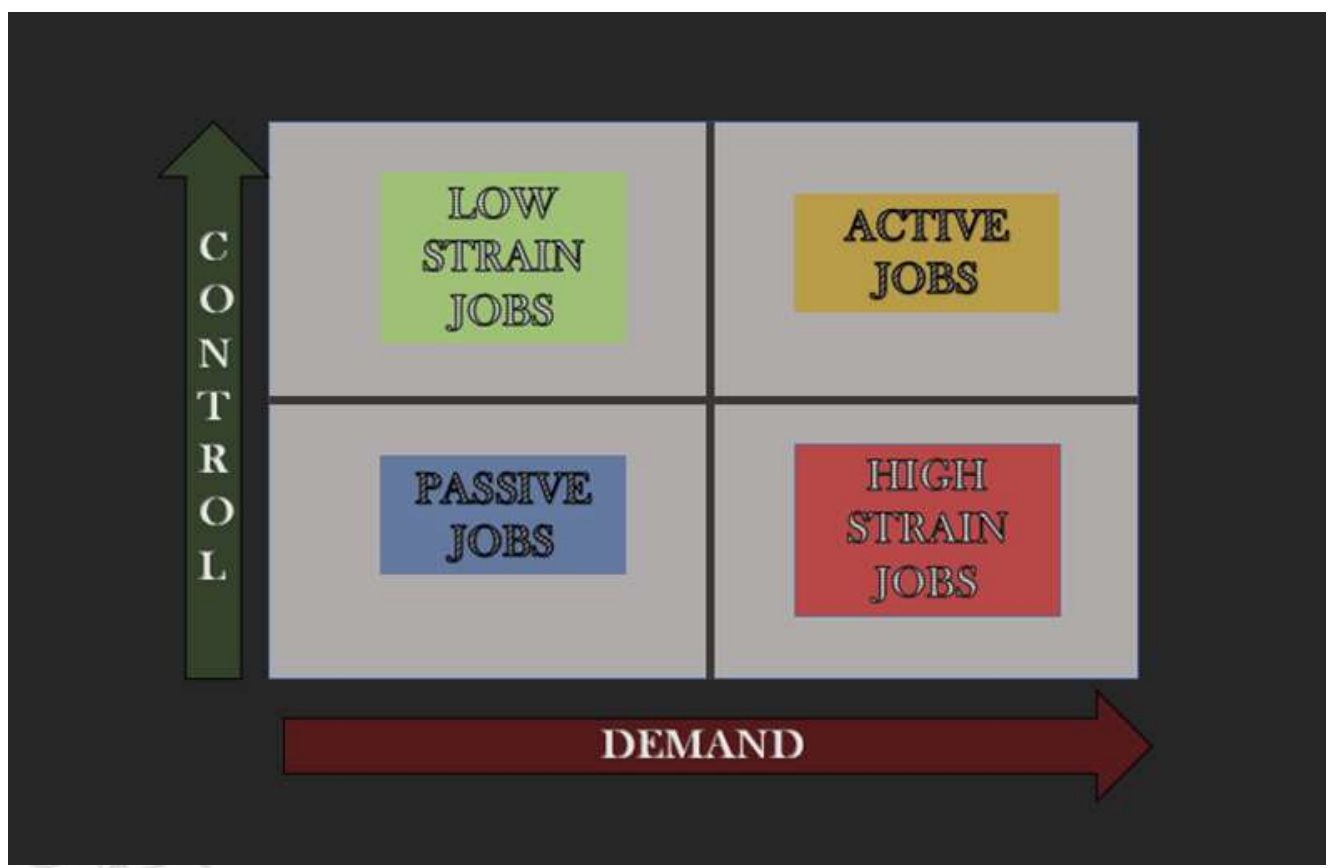

Figure 1. Demand-Control Model (Karasek, 1979; Karasek \& Theorell, 1990)

From the interactive approach, we established:

Hypothesis 2.

The interaction Demand $\mathrm{x}$ Control will have a significant effect on the satisfaction with couple relationships, such that participants with high demands and low control will obtain a lower satisfaction than participants in the other situations.

\section{Controlled variables}

When testing these hypotheses, we will take into account the potential influence of other variables that, as mentioned above, have been identified in the literature as predictors of satisfaction with couple relationships. More specifically, we will consider age, educational background, gender, marital status, having children, number of children, the length of the relationship and neuroticism as variable of personality.

\section{Methods}

\section{Participants}

One hundred twenty four heterosexual employees participated in the present investigation (49\% men and $51 \%$ women) with a mean age of 45.58 years $(\mathrm{SD}=9.53)$, working and with a regular couple $(82 \%$ was married and $18 \%$ was dating). The mean length of the relationships was 21.38 years ( $\mathrm{SD}=11.56)$. From the whole sample, $81 \%$ had children and the average number of hours devoted to family responsibilities was 37.53 hours $(\mathrm{SD}=26.17)$. The percentage of participants according to their educational background was the following: a) Primary education: $3 \%$, b) GED: $14 \%$, c) High school or intermediate vocational training: $20 \%$, d) Associate's degree or advanced vocational training: 33\%, e) Bachelor's degree: $25 \%$, f) Master's degree or PhD: 5\%. The average tenure was 15.46 years $(\mathrm{SD}=11.00)$ and the average number of hours devoted to work was 37.46 hours a week $(\mathrm{SD}=10.21)$. The percentage of participants whose couple worked was $76 \%$. 


\section{Design}

An incidental sample was used and a correlational and cross-sectional design have been carried out in this study.

\section{Instruments}

To assess the demands and the control at work, we utilized the Job Content Questionnaire (JCQ) (JCQ: Karasek \& Theorell, 1990) validated by Escribà, Más and Flores (2001) into Spanish. The questionnaire had 6 items for psychological demands and 7 items for control. The response scale was Likert-type with 5 options, where 1 means "Never" and 5 "Always". Alpha coefficient was 0.72 for the dimension of demands at work and 0.88 for the dimension of control.

To assess satisfaction with couple relationships, we used the Marital Satisfaction Index (ISM) (ISM: Booth \& Edwards, 1983) validated into the Spanish context by Iraurgi, Sanz, and Pampliega (2009). This scale was formed by 24 items with a Likert-type scale with 5 options, where 1 means "Totally disagree" and 5 "Totally agree". Alpha coefficient was 0.96 .

Lastly, to assess neuroticism, we utilized the reduced version of the NEO Five Factor Inventory (Costa \& McCrae, 1992), adapted into Spanish by Cordero, Pamos and Seisdedos (2002). It offers an abbreviated measure of the five main dimensions of factors of personality (Neuroticism, Extraversion, Openness, Agreeableness, Conscientiousness). Given the aim of this study, only the dimension of neuroticism was considered. It was assessed with 12 items, with a Likert-type scale and 5 options, where 1 means "Totally disagree" and 5 "Totally agree". Alpha coefficient was 0.81 .

\section{Procedure}

The set of questionnaires was distributed individually to each employee at the workplace. Participation was voluntary and anonymous, emphasizing that the data obtained would only be used by the researchers and for research purposes. Participants had several days to complete the questionnaires and could ask about any doubt they had, since they were provided with an e-mail address to that end. One hundred and eighty-four questionnaires were distributed and 124 were eventually collected.

\section{Results}

To analyze the results, the statistical package SPSS V.20 was used. Descriptive statistics may be seen in Table 1.

Table 1. Descriptive Statistics

\begin{tabular}{|lcc|}
\hline & Mean & Standard Deviation \\
\hline 1. Neuroticism & 2.51 & .60 \\
2. Demand & 3.31 & .67 \\
3. Control & 3.55 & .88 \\
4. Relationship Satisfaction & 4.30 & .71 \\
\hline
\end{tabular}

First, correlations between all the variables were calculated. Although the results are displayed in Table 2, the most relevant significant correlations for this study were those between educational background, neuroticism and control with satisfaction with couple relationships. Therefore, in the following analyses, educational background and neuroticism will be taken as controlled variables. 
Table 2. Correlations between the variables

\begin{tabular}{|c|c|c|c|c|c|c|c|c|c|c|}
\hline & 1 & 2 & 3 & 4 & 5 & 6 & 7 & 8 & 9 & 10 \\
\hline 1. Age & - & & & & & & & & & \\
\hline 2. Gender & -.13 & - & & & & & & & & \\
\hline 3. Educational Background & .01 & .07 & - & & & & & & & \\
\hline 4. Marital Status & $-.53 * *$ & .10 & $-.28 * *$ & - & & & & & & \\
\hline 5. Children & $.68 * *$ & -.02 & .04 & $-.57 * *$ & - & & & & & \\
\hline 6. Number of Children & .01 & -.08 & -.01 & -.03 & - & - & & & & \\
\hline 7. Relationship Length & $.76 * *$ & -.11 & .09 &,$- 63 * *$ & $.55^{* *}$ & .07 & - & & & \\
\hline 8. Neuroticism & .06 & $.29 * *$ & .06 & -.11 & .13 & .08 & .15 & - & & \\
\hline 9. Demand & -.12 & $-.20 *$ & .07 & -.08 & -.08 & .11 & .01 & -.06 & - & \\
\hline 10. Control & .05 & .04 & $.37 * *$ & $-.30 * *$ & $.21 *$ & -.14 & $.21 *$ & -.13 & $.45^{* *}$ & - \\
\hline $\begin{array}{l}\text { 11. Relationship } \\
\text { Satisfaction }\end{array}$ & -.11 & -.05 & $.20 *$ & .10 & -.11 & -.14 & -.08 & $-.40 * *$ & .17 & $.24^{*}$ \\
\hline
\end{tabular}

Note: $* \mathrm{p} \leq .05 ; * \mathrm{p} \leq .01$

\section{Additive Approach Analysis}

In order to test Hypothesis 1, we performed an ANCOVA analysis, where the quadruple typology of situations that can be obtained according to the combinations of the two dimensions was taken as independent variable; educational background and neuroticism as covariables; and satisfaction with couple relationships as dependent variable.

The quadruple typology was obtained by splitting participants into high and low in each dimension on the basis of the median of the sample in demand and control, and subsequently combining the various possibilities.

The results revealed a significant effect of the quadruple typology (see Table 3). The analysis of multiple comparisons showed significant differences between the low-strain situation (low demand and high control) and the passive situation (low demand and low control) (Contrast estimation $=.47 ; p=.02$ ), and between the active situation (high demand and high control) and the passive situation (low demand and low control) $($ Contrast estimation $=.38 ; p=.02)($ see Table 4$)$.

Table 3. Additive Approach: Demand-Control Model

\begin{tabular}{|lccc|}
\hline Factor & d.f. & F & Sig. \\
\hline Educational Background & 1 & 3.42 & .07 \\
Neuroticism & 1 & 19.60 & .00 \\
Quadruple Typology & 3 & 2.78 & .04 \\
\hline
\end{tabular}

Likewise, neuroticism had significant effects on satisfaction with couple relationships, such that the higher level of neuroticism, the lower satisfaction.

Table 4. Descriptive Statistics in the situations of the Quadruple Typology

\begin{tabular}{|lcc|}
\hline \multicolumn{1}{|c}{ Quadruple Typology } & Mean & $\begin{array}{c}\text { Standard } \\
\text { Deviation }\end{array}$ \\
\hline Passive Situation (Low Demands and Low Control) & 3.99 & .88 \\
High-Strain Situation (High Demands and Low Control) & 4.25 & .80 \\
Low-Strain Situation (Low Demands and High Control) & 4.49 & .39 \\
Active Situation (High Demands and High Control) & 4.53 & .51 \\
\hline
\end{tabular}




\section{Interactive Approach Analysis}

In this approach, an ANCOVA analysis was performed controlling educational background and neuroticism. Job demands and control were taken as independent variables, once they had been recoded in two groups or levels: high and low demand, high and low control. The main effects and the interaction were analyzed. Satisfaction with couple relationships was taken as dependent variable. The results in this analysis (see Table 5) showed that there are not significant effects of the interaction Demand x Control. Nevertheless, main significant effects of control were obtained. The multiple comparisons indicated that participants with low control presented lower satisfaction with couple relationships (Mean $=4.02)$ than participants with high control (Mean $=4.52)$, (Difference of means $=.30 ; p=.03$ ). What is more, it should be mentioned that the controlled variable neuroticism predicted satisfaction. The percentage of explained variance was $27.7 \%$.

Table 5. Interactive Approach: Demand-Control Model

\begin{tabular}{|c|c|c|c|}
\hline Factor & d.f. & $\mathrm{F}$ & Sig. \\
\hline Educational Background & 1 & 3.42 & .07 \\
\hline Neuroticism & 1 & 19.60 & .00 \\
\hline Demand & 1 & .43 & .51 \\
\hline Control & 1 & 4.63 & .03 \\
\hline Demand x Control & 1 & 1.76 & .19 \\
\hline
\end{tabular}

\section{Discussion}

The overall objective of this study was to analyze if the characteristics of the job emerge as direct predictors of the satisfaction with the couple relationship taking Karasek's model (1979) as a theoretical frame of reference. From the additive approach, we predicted that the quadruple typology would have significant effects of satisfaction, such that participants in the high demand and low control group (HighStrain Situation) would present lower satisfaction. From the interactive approach, we predicted that the interaction Demand x Control would have significant effects on satisfaction with couple relationships, such that participants with high demands and low control would obtain lower satisfaction than participants in the other situations.

The results obtained from the additive approach revealed that the quadruple typology had significant effects on satisfaction with couple relationships. The comparisons between the four situations showed differences between the passive situation (low demand and low control) and the low-strain (low demand and high control) and active situations (high demand and high control), such that passive situation presented lower satisfaction than the other two. These results support Hypothesis 1 partially, since although significant effects from the quadruple typology were obtained and participants in the active situation had the highest levels of satisfaction, participants in the high-strain situation did not obtained the lowest score in satisfaction. However, they are consistent with Karasek's (1979) suggestion that passive situation can cause harmful behaviors for employees (and organizations) and that, on the contrary, active situation lead them to develop positive behaviors. In addition, we must consider that, although differences were not significant, participants in the high-strain situation presented lower satisfaction than those in the low-strain and active situations. Thus, the pattern of results is to some extent consistent with the predictions of the twodimensional model and the suggestion that passive and high-strain situations should be addressed in order to prevent psychosocial risks.

Furthermore, from the interactive approach, the results showed that there were significant effects only in the dimension of control, such that the lower the control, the lower the satisfaction in participants. These results do not support Hypothesis 2 because no significant effects were found in the interaction Demand $\mathrm{x}$ Control. These missing effects could be due to the small size of the sample. Nevertheless, these results are 
consistent with model's suggestion that control is the essential dimension, since participants with lowest scores in satisfaction were those with low control. Likewise, the results obtained regarding control are consistent with the suggestions and results from the studies analyzing the relationships between family and work (Allen, Herst, Bruck \& Sutton, 2000; Carlson, Kacmar, \& Williams, 2000; MacEwen \& Barling, 1994; Perry-Jenkins, Repetti, \& Crouter, 2000; Repetti, 1992; Roberts \& Levenson, 2001; Schultz, Cowan, Pape-Cowan, \& Brennan, 2004).

We must emphasize at least two important aspects of the pattern of results. On the one hand, the effects found in relation to the quadruple typology and control emerge once the effects of employees' personal variables, such as neuroticism, had been statistically controlled. They suggest that, regardless of employees' personal traits, the characteristics of the job, such as control (autonomy or chances to make decisions at work, chances to develop their abilities or to have a creative job), continue to have a significant effect on their satisfaction with couple relationships.

On the other hand, from a more positive view of the model, participants in low-strain and active situations (characterized by presenting high control) are those presenting more satisfaction with couple relationships. The results, therefore, not only seem important for the prevention of psychosocial risks in the company, but they could also be important to promote occupational health.

Before drawing conclusions regarding the results, other limitations of this study should be emphasized, apart from the above-mentioned sample size. Thus, the correlational and self-informed nature of the data, become other important limitations.

In short, the main conclusions that can be drawn from the results in this study are that, regardless of employees' traits, such as personality and, concretely, neuroticism, the additive combination of the psychosocial factors of the job, such as the quantity of demands and the level of control that the organizations give to the employees, as Karasek's (1979) two-dimensional model suggests, may influence employees' satisfaction with couple relationships significantly and, therefore, their social health. In addition, control, more than the quantity of demands, emerges as an essential factor, regarding its impact on this satisfaction. In this sense, the present study contributes to the identification of characteristics of the job that can emerge as psychosocial occupational risks affecting not only employees' physical and mental health, but also their social health. Likewise, it contributes to the identification of the characteristics of the job that emerge as positive conditions that could promote occupational health. From this perspective, organizations could try to identify the different situations or combinations that Karasek's (1979) twodimensional model suggests, in order to make the necessary changes and prevent negative effects, as well as promote positive effects on employees' physical, mental and social health.

\section{References}

Allen, T.D., Herst, D.E.L., Bruck, C.S., \& Sutton, M. (2000). Consequences associated with work-tofamily conflict: A review and agenda for future research. Journal of Occupational Health Psychology, 5, 278-308. doi:10.1037/1076-8998.5.2.278

Bakker, A.B. \& Demerouti, E. (2012). The spillover-crossover model. In J. Grzywacz, \& E. Demerouti (Eds.), New Frontiers in work and family research. Hove: Psychology Press.

Booth, A. \& Edwards, J. (1983). Measuring marital instability. Journal of Marriage and the Family, 45, 387-393.

Business Insider (2014). España, uno de los países con mayor tasa de divorcios. El Periódico. Available from: http://www.elperiodico.com/es/noticias/sociedad/espana-uno-los-paises-con-mayor-tasadivorcios-3283830

Cáceres, J. (2012). Separación y divorcio. In: Llavona, L. \& Méndez, M X. (Coord.) Manual del psicólogo de familia (pp. 215-230). Madrid: Pirámide. 
Carlson, D.S., Kacmar, K.M., \& Williams, L.J. (2000). The development and validation of a multidimensional measure of work-family conflict. Journal of Vocational Behavior, 56, 249-176. doi:10.1006/jvbe.1999.1713

Collins, S.M., Karasek; R.A., \& Costas, K. (2005). Job strain and autonomic indices of cardiovascular disease risk. American Journal of Industrial Medicine, 48, 182-193. doi:10.1002/ajim.20204.

Cordero, A., Pamos, A., \& Seisdedos, N. (2002). Inventario de personalidad Neo Revisado (NEO PI-R) $e$ Inventario Neo Reducido de Cinco Factores (NEO-FFI). Madrid: TEA Ediciones, S.A.

Costa, P.T. \& McCrae, R.R. (1992). NEO PI-R. Revised Neo Personality Inventory and NEO Five-Factor Inventory (NEO-FFI). Florida, USA: Psychological Assessment Resources, Inc. Odessa.

Day, E. (Ed.). (2009). Age and marital satisfaction in couples with cancer. Indiana: Purdue University.

Demerouti, E., Bakker, A.B., \& Schaufeli, W.B. (2005). Spillover and crossover of exhaustion and life satisfaction among dual-earner parents. Journal of Vocational Behavior 67, 266-289. doi:10.1016/j.jvb.2004.07.001

Escribà-Agüir, V., Más-Pons, R., \& Flores-Reus, E. (2001). Validación del Job Content Questionnaire en personal de enfermería hospitalario. Gaceta Sanitaria, 15, 142-149.

Eurostat (2011). Population statistics. Available from http://epp.eurostat.ec.europa.eu/

Faulkner, R.A., Davey, M., \& Davey, A. (2005). Gender-related predictors of change in marital satisfaction and marital conflict. The American Journal of Family Therapy, 33, 61-83. doi:10.1080/01926180590889211

Gil-Monte, P.R. (2012). Riesgos Psicosociales en el trabajo y salud ocupacional. Revista Peruana de Medicina Experimental y Salud Pública, 29, 237-41.

Graham, J.M., Diebels, K.J., \& Barnow, Z.B. (2011). The reliability of relationship satisfaction: A reliability generalization meta-analysis. Journal of Family Psychology, 25, 39-48. doi:10.1037/a0022441

INE (Instituto Nacional de Estadística) (2012). Estadística de Nulidades, Separaciones y divorcios. Available from: http://www.ine.es/prensa/np800.pdf

Irauguri, I., Sanz, M., \& Martínez-Pampliega, A. (2009). Adaptación y estudio psicométrico de dos instrumentos de pareja: índice de satisfacción matrimonial y escala de inestabilidad matrimonial. Revista IIPSI de la Facultad de Psicología UNMSM, 12, 177-192.

Karasek, R.A. \& Theorell, T. (1990). Healthy work: Stress, productivity and the reconstruction of working life. New York: Basic Books.

Karasek, R.A. (1979). Job demands, job decision latitude and mental strain: Implications for job redesign. Administrative Science Quarterly, 24, 285-308. doi:10.2307/2392498

Karasek, R.A. (1989). Control in the workplace and its health-related aspects. In S. L. Sauter, J. J. Hurrell, \& C. L. Cooper (Eds.), Job control and work health (pp. 129-159). New York: Wiley.

Karasek, R.A., Baker, D., Marxer, F., Ahlbom, A., \& Theorell, T. (1981). Job decision latitude, job demands and cardiovascular disease: a prospective study of Swedish men. American Journal of Public Health, 71, 694-705.

Kim, H.K., Capaldi, D.M., \& Crosby, L. (2007). Generalizability of Gottman and Colleagues' Affective Process Models of Couples' Relationship Outcomes. Journal of Marriage and Family, 69, 55-72. doi:10.1111/j.1741-3737.2006.00343.x

Linzer, M., Gerrity, M., Douglas, J.A., McMurray, J.E., Williams, E.S., \& Konrad, T.R. (2002). Physician stress: Results from the physician work life study. Stress Health 18, 37-42. doi:10.1002/smi.917

MacEwen, K.E., \& Barlin, J. (1994). Daily consequences of work interference with family and family interference with work. Work and Stress, 8, 244-254. doi:10.1080/02678379408259996

Martín-Sanz, N. (2009). Estrés laboral, barrera para el crecimiento. (Unpublished master's thesis). Complutense University of Madrid, Madrid, Spain.

Mora, M.R., Gómez, M.C., \& Rivera, M.E. (2013). La satisfacción marital y los recursos psicológicos en las parejas con y sin hijos pequeños en pro del bienestar familiar. Revista de Psicología de la Universidad Michoacana de San Nicolás de Hidalgo, 10, 79-96.

Moral, J. (2008). Modelos predictivos y senderos de ajuste diádico por géneros en parejas casadas. Ciencia UANL, XI (002), 185-192. 
OMS (Organización Mundial de la Salud) (2006). Documentos básicos, suplemento de la 45a edición, octubre de 2006. Available from http://www.who.int/governance/eb/who_constitution_sp.pdf

Pelfrene, E., Vlerick, P., Kittel, F., Mak, R.P., Kornitzer, M., \& De Backer, G. (2002). Psychosocial work environment and psychological well-being: Assessment of the buffering effects in the job demandcontrol (-support) model in BELSTRESS. Stress Health, 18, 43-56. doi:10.1002/smi.920

Perry-Jenkins, M., Repetti, R.L., \& Crouter, A.C. (2000). Work and Family in the 1990s. Journal of Marriage and Family, 62, 981-998. doi:10.1111/j.1741-3737.2000.00981.x

Repetti, R.L. (1992). Social withdrawal as a short-term coping response to daily stressors. In H.S. Friedman (Eds.) Hostility, coping, and health. (pp. 151-165) Washington DC: American Psychological Association.

Roberts, N.A. \& Levenson, R.W. (2001). The remains of the workday: impact of job stress and exhaustion on marital interaction in police couples. Journal of Marriage and Family, 63, 1052-1067. doi:10.1111/j.1741-3737.2001.01052.x

Schulz, M.S., Cowan, P.A., Pape-Cowan, C., Brennan, R.T. (2004). Coming home upset: gender, marital satisfaction, and the daily spillover of workday experience into couple interactions. Journal of Family Psychology, 18, 250-263. doi:10.1037/0893-3200.18.1.250

Vera-Herrero, J. (2011). Patrones de comunicación en parejas y su relación con la satisfacción marital en profesores de una universidad privada de Asunción. Available from http://pepsic.bvsalud.org/pdf/eureka/v8n2/a06.pdf

Villamizar-Carrillo, D. (2009). Las representaciones de las relaciones de pareja a los largo del ciclo vital: significados asociados y percepción del cambio evolutivo. Available from http://www.tesisymonografias.net/representaciones-de-las-relaciones-de-pareja/1/

Weinstein, L., Powers, J., \& Laverghetta, A. (2010). College Students' Chronological Age Predicts Marital Happiness Regardless of Length of Marriage. College Student Journal, 44, 413-416.

Zicavo, N. (2008). La alienación parental y el proceso de la padrectomía. Revista Cubana de Psicología, $\mathrm{N}^{\mathrm{o}}$ Conmemorativo. 